\title{
Mapping outside the square: cultural mapping in the south-east Kimberley
}

\author{
Kim Mahood
}

In June 2005 I carried out a 'cultural mapping' project at the invitation of the Walmajarri Aboriginal owners of Paruku (Lake Gregory) in the south-east Kimberley. The team of white people with their varied expertise who assisted me were geomorphologist Jim Bowler from the Department of Earth Sciences at the University of Melbourne, tourism consultant and trainer Petrine McCrohan from Kimberley TAFE, anthropologist Catherine Wohlan from Broome, linguist Eirlys Richards, also from Broome, Mark Ditcham, co-ordinator of the Paruku Indigenous Protected Area, and John Carty, an anthropology doctoral student working for the Palyalatju traditional medicine organisation based at the nearby Balgo community.

The project's intention was to bring together scientific and Aboriginal knowledge of the Lake Gregory area, to record traditional stories and oral histories, to make photographic and video documentation of campsites, archaeological and geological sites, bush food and bush medicine, and to record place and family names. The central template for this recording process was a large painted canvas map, on which were inscribed dreaming tracks, place names, soakwaters and campsites, the precise areas to which people's ancestors held entitlement, and the locations where large groups of people came together during the period of first encounters between white settlers, missionaries and Aboriginal people. The revisiting of locations and camping out on country provided an opportunity for elders to pool their knowledge of names, places and events now at risk of being forgotten, for the purposes of educating their children in their country and their culture. The inclusion of non-Aboriginal information was an incremental shift towards bridging the gap between knowledge systems, and an attempt to provide a basis for future planning of the management of the lake. In the process of the mapping exercise questions were raised about environmental maintenance, the protection of artefacts and the increasing impact of tourism. The map and recorded material were later exhibited at the Balgo Culture Centre, allowing the Walmajarri lake people to present their own culturally coherent identity within the large and diverse mix of language groups based in and around Balgo.

This paper is a reflective piece with no academic pretensions. It attempts rather to evoke the place and its people, describing the sometimes uneasy interface between white and Aboriginal knowledge systems, and leaving open the constantly evolving possibilities of that encounter. As part of the essay I have included the 'storybook' pro- 
duced for the Aboriginal participants, to illustrate the gap between written and oral/ visual ways of presenting information. Since I am myself a writer and visual artist rather than an academic the gap is not as great as it otherwise might be.

\section{May 2005}

Heading west again, towards what feels like home, or the nearest thing to it I have. But always when I arrive there's that small quiver of ambivalence before the familiarity takes over, the pleasure to be back, the daily involvement in the project to hand.

This need to keep covering the same ground, straddling the worlds. And they are worlds that don't make much space for each other, in spite of the fascination, even obsession they have for each other.

This is a story without edges, grounded in the lives of contemporary Aboriginal people but inflected with the preoccupations of a white Australian imagination. It is full of contradictions and loose ends and unfinished stories, its templates formulated in the Dreaming and the Pleistocene. Its narrative is structured around a journey that is circular and repetitive, formed by and giving form to a particular place. The place is real, but it can also be read as a metaphor, the inland lake as palimpsest, engraved with the events of deep time. Its ancient geography can be read through the processes of erosion and sedimentation, and those processes continue to work on the living culture.

On the cusp of the Tanami and Great Sandy Deserts lies a remnant palaeo-lake that goes by many names. On early maps it is called Gregory Salt Sea, named in 1856 by Augustus Gregory, the first white explorer to reach it. The faint poetic echo has since disappeared, and modern topographical maps refer to it simply as Lake Gregory.

To its traditional Walmajarri owners it is known variously as Mulan lake, Paruku, Yampirri Yampirri, Muntakuyungajirta (stomach without meat), and a host of names that describe specific parts of what is in fact a complex system of fresh and brackish lakes. The names mentioned refer to the biggest of the lakes, a body of approximately eighty square kilometres of water. Three hundred thousand years ago it was ten times that size, and the trip I made in June 2005 with a group of traditional owners and an assorted collection of white professionals was a journey through time as well as country.

Some years ago in the melting pot of a ceremonial gathering of Aboriginal women, I had a conversation with another young white woman who, like me, had been thrown by circumstance into the event. She was assisting a scientist in gathering information around Lake Gregory. The scientist was the geomorphologist Jim Bowler, and among his reasons for studying Lake Gregory was its similarities to Lake Mungo.

Like many white Australians with a passion for Australian prehistory, my imagination had been captured by Jim Bowler's discovery of the ancient burial sites at Lake Mungo, and my own associations with Lake Gregory stitched the two places together in a pattern I was not ready to examine, but which did not go away. In the sea change of the following years I returned many times to the Tanami, re-establishing old relationships and forming new ones, and two years ago was invited by the traditional owners 
of Lake Gregory to work on a project with the women at Mulan, the Aboriginal community near the lake. Among them was Shirley, the daughter of a man who had worked as head stockman for my family during the years we lived in the Tanami, and in the course of many conversations I spoke of the symmetries and differences between Mulan and Mungo, and what they had to reveal about Aboriginal history and prehistory.

Shirley had never heard of Lake Mungo, and had scant knowledge of the scientific discoveries that continue to reveal the prehistory of Australia, but the idea excited her, and together we formulated a plan, which we put to the community, to invite Jim Bowler back to make a trip with the traditional owners around the lake, revisiting the sites of traditional and scientific significance. We would make a map on which all this information could be written, a document that would record Aboriginal knowledge and white science, pastoral history, mission days and land rights, to see where they intersected and overlapped.

The lake country is a significant arid wetland and an Indigenous Protected Area, the Aboriginal equivalent of a National Park. It has been a cattle station and the site of a landmark return of country to its traditional owners. Stories, like water, accumulate in it Its current owners grew up in the cattle industry, though the oldest of them were born in the bush. The stories of its creation are told and retold, of the two dingoes who chased two emus down the channels of the Sturt Creek floodout, killed them at the junction of the big lake, and went on into the ground at Pangkupirti Creek, where the salt trails of their sweat are still visible.

From time to time the lake dries up, and occasionally it floods out to something approaching its original dimensions. As a more or less permanent body of water, it is one of the most important arid wetlands in Australia, the lake and its surrounding grasslands supporting many varieties of birds, plants and animals. Since its declaration as an Indigenous Protected Area under the aegis of the Department of Environment and Heritage, the World Wildlife Fund and Territory Parks and Wildlife have assisted the community with field trips to gather information about plants and animals, their taditional uses and significance as well as their scientific identification, in order to plan for long-term environmental management.

Jim Bowler's long association with the lake was for what it could reveal about clinate change in the northern part of the continent. Three hundred thousand years ago fustralia was much wetter than it is today. Between ten and twenty thousand years ago it was a great deal drier. During that dry phase a number of inland lake systems, ixcluding Lake Mungo in NSW and Lake Gregory in the southeast Kimberley, dried up. lake Mungo never refilled, and so began a process of erosion that eventually revealed the ancient burial sites and pushed back the known period of Aboriginal habitation to frrty thousand or more years ago. The Mulan lakes are not eroding, and so have not revealed spectacular ancient grave sites. What they do instead is reveal contemporary kboriginal life in all its complexity, through the period of first contact, pastoral stations and missions to land rights, environmental issues, mining and tourism. 


\section{June 2nd Mulan}

Woke up at 3 am feeling completely overwhelmed by what I've taken on fear of no-one turning up, fear of too many people turning up, fear of not being able to orchestrate anything. And knowing I had to go out there in the morning and appear to know what I was doing. I feel like a dilettante, blundering into projects for which I am equipped only with a kind of laissez-faire optimism that l'll pull it off somehow.

We made our base camp at Yunpu, one of the freshwater lakes on the western side. The water was shallow and aquamarine, the white lake sand rimmed by red dunes that marked an earlier shoreline. Flotillas of pelicans fished the middle of the lake and the women fished the edges. In the afternoon we unrolled the map, a canvas two and a half metres square onto which I had painted a scaled-up version of a topographical map of the lakes. It was naming time, an exercise in collective memory and the expertise of our linguist, who spelled the names for my untutored ear while I crawled about and marked them in chalk under the argumentative guidance of the elder women. From the outset it was clear that the map wasn't big enough. Its squared edges and my notion that such arbitrary boundaries would be adhered to made no sense to people who had walked the lake environs as children and carried their knowledge of country in their bodies. The first overlapping of white and Aboriginal systems of knowledge was an exercise in expediency.

'Puttem', I was told peremptorily, 'you can fixem up later'. I puttem, and the map's edges became congested with information which I would later transfer onto canvas extensions.

\section{June 3rd Yunpu}

Sat with Fatima, Minnie, Anna and Frank after dinner - they told stories of old times and dreadful cruelty towards Aboriginal people, grandparents and great grandparents of this mob, horrible stuff, still very fresh - punctuated by great amusement when Minnie remembered some entertaining detail. She's a story teller of little English but great energy and humour. Anna muttering in the background with fastidious distaste.

There's nothing people like better than camping out on country. It doesn't happen often enough, now that most people live in sedentary communities and are limited by the lack of functioning vehicles. Because there was a fairly large contingent of kartiya (whitefellows), we were expected to have our own campfire, though it was equally expected that we would wander and socialise at the other fires. The rangers had their own fire some distance away, where they played a constant stream of country music on a portable cd player, and the kartiya camp was closely flanked by two fires that served a rough division of family groupings.

Mozzie domes were de rigeur, the pop-up variety that can be erected in seconds, to provide protection from night dangers. There was the usual head-shaking at the kartiya habit of solitary swags and tents, and our apparent immunity from wandering spirits. In the night one of the old men was 'choked' by one such being, although next morning he seemed relatively unscathed.

We spent the morning in camp putting on the map the names of ancestors who belonged to specific places, and from whom my informants took direct lineage. One of 
them became a falling star, and we traced his trajectory from a mountain in the east to the place where he went into the lake. This was important business, establishing the credentials of the living generations, making memory visible, insurance against the instability of change and the steady loss of oral knowledge. People made decisions about the places they did not want tourists to visit, and the sites sacred to either men or women.

The story of the two dingoes that created the lake has many versions, among them the one given out for general consumption and the restricted version to which only men have access. Jim's white-bearded presence lent our project serious masculine credibility, so when the time came to tell the story the women removed themselves to the lake. It was only the telling that was restricted, the place names and the track of the dingoes was marked in chalk onto the map, though later when I raised the question of whether it could be painted on like the other details I met with uneasiness and no clear answer, so left it as a fragile tracery of chalk.

\section{June 4th Yunpu}

Four fires, voices murmuring in the darkness. Light wind and the sound of ducks on the lake. Kartiya all busily flossing their teeth. John said 'It's times like this you feel the cultural gap.'

Have to rescue my shovel from Evelyn, and my blue enamel billy from Fatima, who has designs on it. This morning Evelyn extracted a fat pointed grub from a gall and made me eat it. A burst of juice accompanied by a wriggle, not too bad apart from feeling the point all the way down. Couldn't face the little pink maggot-like grubs in the bush coconut.

We had several agendas for the trip, one of them being to revisit the locations where Jim had taken drilling samples, so we drove to the nearby dunes which Jim's work had identified as the shoreline of approximately 100,000 years ago, the characteristic lunettes formed on the western lake edges by the prevailing winds. ${ }^{1} \mathrm{He}$ drew a mud map of the lake's evolution, pointing out shell and limestone evidence of recent and ancient floods, and demonstrated how the termites carry ancient shells up from under the ground, where they can be found embedded in the mounds.

The following day we travelled further west, beyond a second dune shoreline laid down approximately 200,000 years ago, its colour a deeper red than the younger dunes, to where the country rose in a broad shallow sweep through a clutter of wattle and grevillea, and the sand grew redder still. This was the great dune of the original lake edge, established between 250 and 300,000 years ago. ${ }^{2}$ At its apex was a grove of old desert oaks, the largest of which Jim had sketched on his original field notes.

'This the Japangarti tree', the old ladies announced, and Charmia wept for the Japangartis who had died. They held Jim's laminated elevational map, which showed the extent of the old lake and the broad palaeo channels that once flowed from it to the western coastline, and awarded Jim the name of Japangarti, brother to the old man tree. Charmia led the women in singing the song for the tree, and then they laid the map down and danced.

1. Bowler, Wyrwoll and Lu 2001.

2. Bowler, Wyrwoll and Lu 2001. 
The scientific story of the lake's evolution, with its evidence of ancient shells and shorelines and its one-time connection to the sea, was met with curiosity and interest from the traditional owners, but without surprise. Their own Waljirri tells of a time when barramundi, crocodiles, turtles and other saltwater and estuarine creatures lived in the lake. Jalka the Great Egret took them out of the lake towards the sea, dropping some of them on the way, and leaving only the Spangled Perch and eel-tailed Catfish which live in the lake today.

A few kilometres west we reached Well 50, the last of the desert wells on the Canning before the stock route swings north-east towards the lake and the Sturt Creek channels. The well itself was a limestone trench full of bushes and rubble, with a battered tin baler beside it. The old men walked around patting the fallen timber rails. They had come here as young stockmen, and most had family who had travelled the Canning in the days of droving cattle. Evelyn told the story of her husband, who had walked away from the stock camp at Well Fifty after a fight.

One time when my husband was working on Billiluna cattle station, the stockmen went droving cattle down the Canning Stock Route with Wally Dowling. My husband was a young bloke back then maybe in his teens. When they had left the lake and got to Jikarn (well 50), they camped there. That night a fight started between the stockmen. My husband got upset and walked away from the camp and started making his way back to Billiluna. You know that well, that place called Jikarn with a big hill nearby on the south side, well it was the other side of that hill that the stockmen were camped. There was a tree there they call ngurlunyngurluny, that's the Kukatja name for it. It's a scary tree he used to tell me. From there, that tree followed my husband as he walked along by himself. He was frightened. So he climbed up the other trees and slept there in the branches to protect himself from the ngurlunyngurluny that was following him.

From there he just kept on walking, walking. When he came to a claypan, he looked around everywhere for the soakwater and he found it. Then he started to dig. As he was digging for water it started to come up through the ground. Then he started to clean the water by scooping it out with his billy can. When it was clean, he drank it. He also brought some sugar, tealeaves and tobacco from the stockcamp so that he would have something to eat and drink along the way.

He kept walking till he came to a bore and rested there. As he was resting, his brother (pamarrngawurr) a spirit person, like a guardian, started to throw little stones at him to let him know he was there. 'I know you, you're my cheeky brother.' Jalyaku said to him.

Pamarrngawurr said, 'Wait till morning and I'll leave you some food as we head off tomorrow.'

So the next morning he ate the food his brother left for him. After he had set off, he found a motorcar track. Then he saw some camel tracks. 'What's this?' he thought. 'I don't know this track.' From there he came to sandhill country and it was hard work climbing them. He got very tired and couldn't go any further. He staggered on until he found some shade and fell down and lay there. While he was lying there, two men found him. They were stockmen who had followed his tracks from Jikarn camp. They saw that he had been staggering as he walked and they were worrying for him. They all rested there, and after recovering, the next day they got up and headed towards the lake. They came to Kurtu Soak near a windmill. From 
Kurtu Soak they went east across the lake. Then a priest found them there and offered them a ride in his vehicle. I think it was Father McGuire. He said to them, ' $\mathrm{I}$ 'll take you to Old Balgo Mission. ${ }^{3}$

\section{June 5th Well 50}

Retreated to the wattle shade of a claypan to boil the billy, had been there half an hour when a safari of four wheel drives pulled in, tourists from a four wheel drive adventure club on their last leg up the Canning. Spokeswoman for the tourists was a robust lady who showed no fear of transgressing cultural protocols.

'Out for a picnic are you?' she asked. And within minutes, to the women, 'Will you dance for us?'

All the kartiya in the party went rigid. John stayed sitting, head down, blackfellow mode, I reverted to cryptic pastoralist's daughter, Catherine to affronted anthropologist, Petrine to tour guide operator. Jim remained the bemused boffin. Eirlys, our wonderful linguist, was non-committal at being mistaken for the cook.

We felt - what? Offended, protective, trespassed upon. All these things, but I think also we wanted to differentiate ourselves from these outsiders with whom we shared a skin colour. The Aboriginal mob had no such inhibitions.

'Sure,' they said. 'We'll dance for you, if you pay us.'

Anyway, no money changed hands and nobody danced. And to be fair to us, we'd just spent several days in another world, and the arrival of the safari broke into a kind of enchantment. It was the matching cotton sweatshirts that did me in.

Tourism is a contradiction that has to be addressed. Part of our project was to work out practical approaches to developing the lake for tourism, since it offers one of the few viable opportunities for the community. Travellers like the ones we encountered come up the Canning from the south and veer in to the northwest corner of the lake. There's a steady pilfering of artefacts, and the lake people are caught in a bureaucratic bind which forbids their removal to the community for safe-keeping. We took these questions with us to a sand dune jutting out into the lake, a place which after a big wet season is a perfect campsite for swimming and fishing, and from the profusion of artefacts lying about in the sand has been used as such for generations. There was a frenzy of collecting, until Jim's plaintive protests convinced people to put them back where they had found them. There was lively discussion in which people debated the pros and cons of signage, afraid that if the locations were made public it might simply invite thieves.

Driving home, Monica leaned over and dropped a pile of flint chippings in my lap.

3 Story told by Evelyn Clancy at Well 50 , recorded and translated 6/6/05 by Eirlys Richards, assisted by May Stundie. 


\section{June 6th Comet}

After lunch took crew and Bessie, Shirley and Doonday out to Comet (old mission site) to film the site where the dingoes went into the ground. Seems to be no restrictions on doing so. Doonday did the 'Keep going' number across buck spinifex and wattle stakes, but I insisted we take the lesser path along the creek. Got bogged in the sand, not too badly, so we walked from there. Salt trails in the creek indicate the sweat left by the running dogs. Some argument between Bessie and Doonday about the actual location where the dogs went in. They settled on a place where water still lay in a bend, Doonday told the story with Bessie filling in the gaps. My dog became alert and agitated, perhaps sensitive to the presence of the ancestral dogs.

Later when we checked the film it looked wonderful, late afternoon light, the red eroding banks of the creek with the white drifts of salt, and two photogenic elderly people. Unfortunately the sound had not come through. Maybe the dingoes over-rode Doonday's authority to show us the place.

Yutukani pajarranya Parnkupirtila kunyarrkujarrarlu

Kurlirra pajarranya yutukani

Yani pajarra wurnala kakarrara

Kanya pajarranyalu Clumpyjarra kunyarru

Kanya-jarranyalu Malarntawu kakarra, yini Malarn

Takurryani pula kunyarrkujarra kinkijartu. Wali

The two dogs put Clumpy and me down at Parnkupirti Creek

They put us down in the south

Then we went eastwards

The dogs took Clumpy and me to a place called Malarn in the east

The two dogs with their bellies full went into the ground there. ${ }^{4}$

\section{June 8th}

Circumvented some money and ego problems this morning, re who has elder status, who is offended at being left out etc. Also set up spreadsheet on office computer. Book-keeping and cultural housekeeping.

At Lirra the old men pulled rank, wouldn't let the women accompany them to the ceremonial ground on the point, much to Bessie's disgust - 'We go fishing there all the time!'

Looking south over the lake an old stockman indicated a place where there used to be an island, now covered with water, and told the story of his grandfathers being pursued by kartiya with guns after killing two bullocks. The men escaped to the island and were protected by a water snake, which threw up a great wave that pushed the pursuers back and deflected the bullets.

4. Story told by Boxer Milner in 'Minya Manpangu Marnu Yapajanka, Stories From Our Childhood', by Mulan Sorytellers KLRC 1999 compiled and translated by Eirlys Richards.

Translator's note: This enigmatic story may need a word of explanation. Boxer and Clumpy are brothers whose country lies around Parnkupirti Creek. They identify with features in the landscape: two rocks which were put down in the Waljirri or Dreamtime. Here Boxer alludes to an episode in the Waljirri story of the two dogs who put the rocks in place. Note that Boxers refers to the rocks as himself and Clumpy. As in all such stories, there are many layers of meaning which Boxer does not attempt to explain here. 
And one water snake, kalpurtu, you know. He been pushin that water right back! Pushin the Kartiya right back in kankarra, like sideways. Water been pushin them right back. They been shootin but nothing; half way they been fallin down bullets.

... my one kilaki now, he never been come close up to Kartiya, wild one, till long time, till last. Till he been come Kartiya good ones, all the cheeky ones they bin get away now. They bin shootem my grandfather through the water with rifle, they never get him ... shooting but no they couldn't get him, wasting bullet. ${ }^{5}$

A much-told Waljirri story is that of Jintipirriny, Willy Wagtail, who was overlokked at a ceremonial gift-giving. He went to his cousins, two snakes that live in one of the deep channels feeding into the main lake, and told them of the slight. Angry on his behalf, they travelled west and swallowed all the people, returning to the lake where they vomited up the bones in the place called Kiji, which means bone. In the process of witing it down this story underwent some revisionism at the hands of the Aboriginal asistant linguist, a woman of strong personality, storytelling skills and definite views. Afollower of a charismatic Christian religious sect, she added a moral slant to the story.

That's why in our Waljirri people and children today are never to tell lies or to be greedy and selfish and they must always share their things. Otherwise something like this might happen to them.

I vas taken with this interpretation, which gave no indication that Willy Wagtail's ervy, resentment and desire for revenge, or the mass murder of people by his cousins the snakes was unreasonable.

What became evident as the project developed was that the map was a document that worked on many levels. It was a kartiya form of imagining the land, based on techndogies that provided a recognisable brand of 'accuracy', but because of its scale, the fait that it was painted on canvas, and because the lake people controlled the information that went onto it and chose the symbols to represent locations and activities, it caried its own cultural legitimacy. The process of collective remembering laid to rest much of the argument around who had legitimate claims to which part of the lake, as eah person witnessed the names of their forbears written into the story at the proper loation.

The recording and transcribing of stories was of particular importance, the proces we evolved consisting of reproducing the story in Aboriginal English and having a litrate family member read it back to the storyteller, usually surrounded by a captivated audience.

It was a language rescue operation too, with only a few Walmajarri speakers left inthe community, the lingua franca of the region fast becoming Kukatja.

The things that stay with me are the names, like a litany, a mnemonic device taight to children so that they knew where the water was, always the water, soakwater ard living water. Pankupirti, Walakarri, Ngarrmanu, Kakalyalya (my favourite, meaning cckatoo), Yirrkaja, Liwarrjartu. Rhythm, sound, pattern, life, survival.

Bessie named the sites on a painting she had done some years earlier for her dughter, and when she couldn't remember a name she said, 'Gettem that big map'.

5. Story told by Frank Clancy at Lirra, 8/6/05, recorded and transcribed by John Carty. 
The painting recorded all the soakwaters where water could be found in the dry times, the blue circles placed in the same orientation to one another as the names on the big map. Later, using the same process, we named the locations on a painting of the lake in flood, the painter having died the previous year.

Having so recently visited many of the locations it was a strange privilege to feel the relationship of each place to the other on both map and paintings, to know them physically and to experience one's own vestigial sense of embodied knowledge.

\section{Jun 13th}

Drove to Balgo to pick up canvas for extensions on map. On return found May, Bessie, Lulu sitting outside Bessie's house. Realised as I got out of car I had left my handbag at Balgo. Lulu said we needed to call a meeting because people were grumbling about money. I performed a somewhat orchestrated tantrum, that if people thought I would cheat them then I couldn't work for them any more. (Evelyn had conveniently forgotten she had bought a coat and two tins of tobacco.)

They pacified me, 'No Napuru, you right, they shouldn't humbug' etc.

I wasn't really angry, but exasperated enough to put on a good show. My tobacco was in the handbag.

The map is a work in progress, part of a canvas that has no boundaries. From collective memory to individual recollection it's a gathering of stories, a realignment of old alliances, a reopening and laying to rest of old controversies. Often I was hardly aware, among the preoccupations of managing the project, of the hidden politics that were being thrashed out.

It's a cross-cultural document carrying the authority of white knowledge systems overlaid and undercut by the templates of Aboriginal knowledge. Around it hovers the multiple voices of people, released whenever the map is unrolled. It's a moving, storied document that holds something of the noise and scale of a painting, but communicates directly to a white audience as well. Its borders are active, already the people with links north want to make a map of the flood channels of Sturt Creek and beyond.

The link to Mungo that captivated my imagination and that of the kartiya to whom I spoke of the project was not significant to the traditional owners of the Mulan lakes. Mungo was far away, in someone else's country. What interested them, endlessly and in all its variety, was their own place, in which the past was transparent and constantly manifest in the present.

Mulan's legacy, as important in its way as Mungo, is more difficult to access because it is through the agency of living people, with their contemporary aspirations and agendas. But for those prepared to pay the respect and attention, to put in the time and manage the contradictions, it's a dynamic repository of hidden histories, a gift to a future in which we are all implicated.

There are two versions of this story, one constructed for a highly literate readership and the other for the people to whom the story belongs, many of whom have little or no literacy. On the following pages is the version created for them. It seems at face value a simple picture book, but like the map it is full of hidden politics. People are located in the places for which they have the right to speak, telling the stories they have 
the right to tell. Every image carries multiple meanings, confirming relationships to specific places and triggering a network of associations. People sit down together and flick through it, re-telling the stories and segueing into recitations of family trees that descend from the ancestral names, identifying the places, constantly recapitulating who belongs to which country. An old woman told me, on looking through the book, 'We used to know where the boundaries were. That's how we managed disputes and problems. Everybody knew who had the right to speak for which place.'

\section{Mapping Mulan Big Book document}

Drilling auger holes into sand dunes and sifting the sediments of memory can only reveal a partial picture of the ancient geological and cultural topography of the lake country. This is part of its allure, that it will always conceal more than it reveals. On a less romantic level the processes of erasure continue through the depredations of expanding herds of brumbies and poorly-managed cattle grazing. There is evidence that the lake edges and sites rich in artefacts are under threat, the metaphor of the palimpsest taking on a certain environmental urgency.

There is an urgency too among the older Walmajarri people to have things written down, knowing that their children are not learning the country as they did, by travelling through it and absorbing its detail through the repetitions of story and physical encounter. They know that country is still the most important legacy they have, the one resource that might counter the cultural erasure that is occurring through sedentary lifestyles, western popular culture and substance abuse.

The significance that elders attach to the right people speaking for country can't be overstated. What is beginning to emerge through the mapping exercise is a template by which certain essential structures of traditional political life can be represented in an easily accessible form. Whether that knowledge can be transferred in any constructive way to contemporary community life is an open question. The map itself remains a work in progress, and represents in its way my own commitment to finding shared ground that will hold into the future.

\section{Reference}

Bowler, JM, Karl-Heinz Wyrwoll and Yanchou Lu 2001, 'Variations of the northwest Australian summer monsoon over the last 300,000 years: the paleohydrological secord of the Gregory (Mulan) Lakes system', Quaternary International 83-85: 6380. 


\section{Mapping Mulan 2005}

The following pages reproduce at a smaller scale and in black and white a version of the book Mapping Mulan 2005. The original is in colour and is A2 in size. It was produced by the Registrar of Aboriginal Corporations, an Australian Government publication. Copyright is held by Kim Mahood and Walmajarri traditional owners of Lake Gregory/Paruku.

Design is by Lisa Donnelly. Text by Kim Mahood in consultation with May Stundi. Permission to use the book has been given by the Walmajarri traditional owners of Lake Gregory/Paruku.

Photographs marked with a circled ' $\mathrm{P}$ ' are by Petrine McCrohan. The other photographs are by John Carty. They were all taken in the Lake Gregory area in 2005. 
KURRTUTU KURRTUTU

JARTA

NGANPAYIJARRA

NGAMAJI

LUPARN

WALAKARRI

PUNGKARLU PUNGKARLU

PARTIJI

KAKALYALYA

JIRRIPARTU

KIRILINYJARTU

WARNKUPARUK

WIRRARARR

LUNGKURRNGAN

YIRRKAJA

YAMPIRRI YAMPIRRI

MUNTAKUYUNEAJIRTA

KURNTUKUTA

PANEKUPIRTI

NGARRMANU

KUYURRUYURRU

MATU

PUYI PUYI

LIWARRJARTU

MANYURALI

KILANGKARRA

LUNGKURTA

NYINYINGAN

PINTIRRIJARR

KIRTA

LIRRA

KIRLWA

PIRRNGAN PIRRNGAN

KIJI

LAPALANI

KUMPUJUWAL

LAMANPARAK

LANGAN

JAWAL

WARAWARA

KURTA SOAK

WALYARRA

PULPALY

YUNPU

JALYIRR

KARPIJI

KUTAJARRA

YURRUNYUPARTU

RILYI RILYI

KILANG KILANG

KARNAWA

PARNANY PARNANY

LURRPUNGU

WIRRINY

JURRULUNGKUJARRA

NYARNAJARRA

MUNTUN
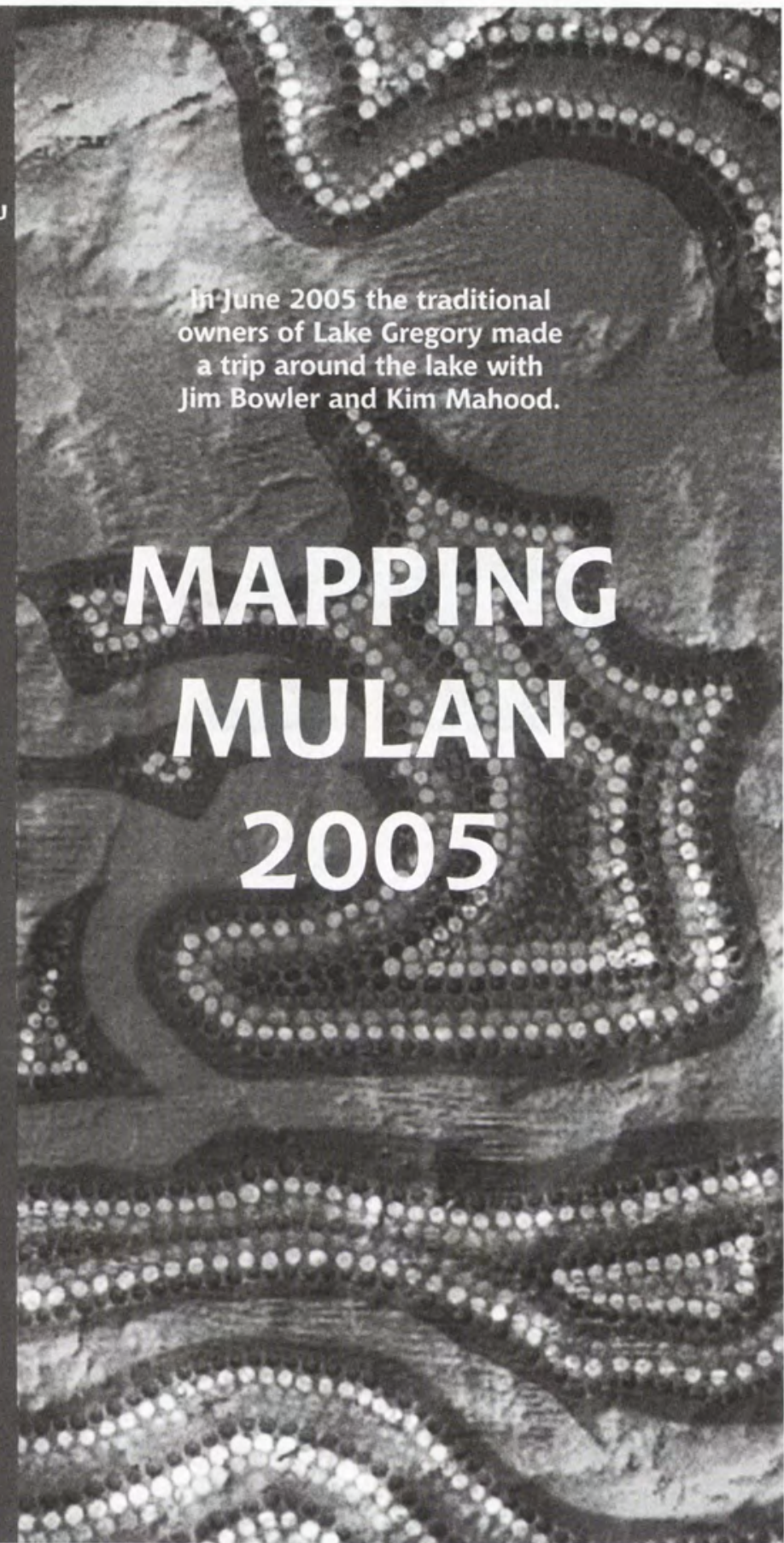


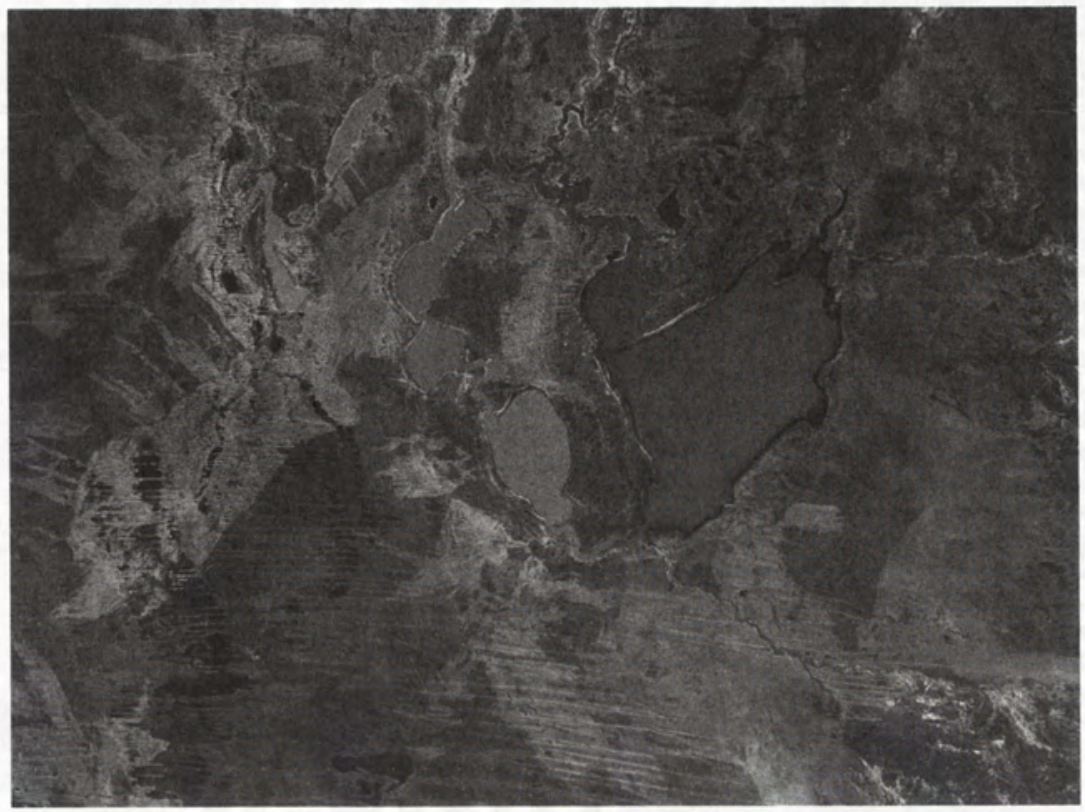

Satellite map of Lake Gregory

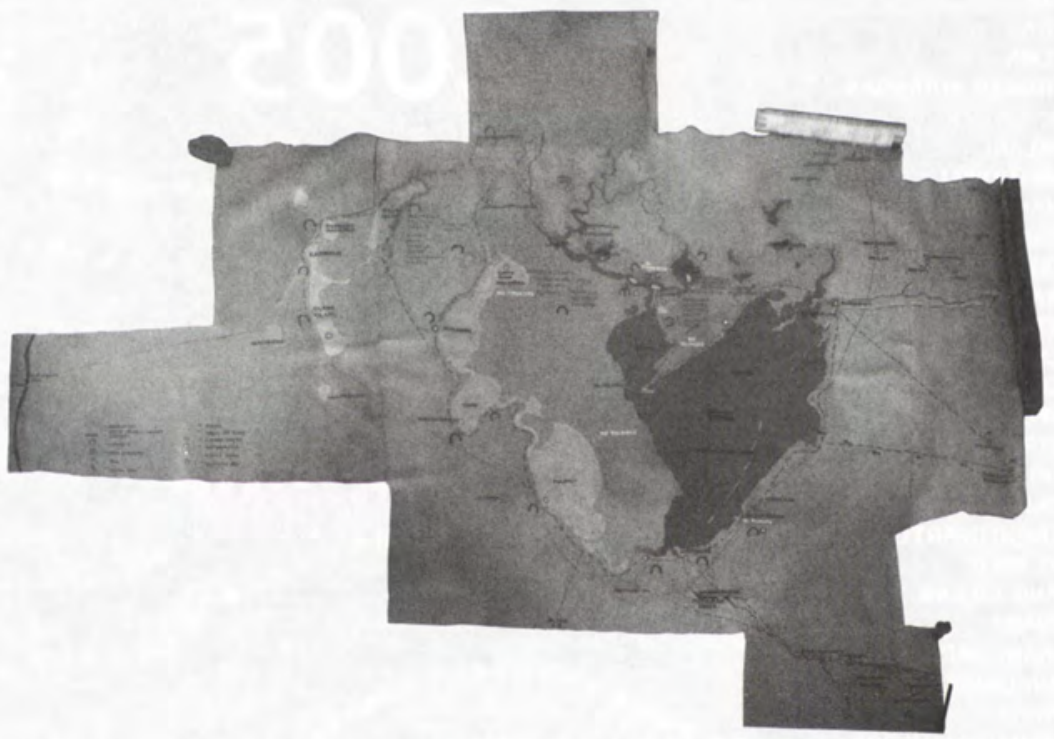

Painted map of Paruku/Lake Gregory 

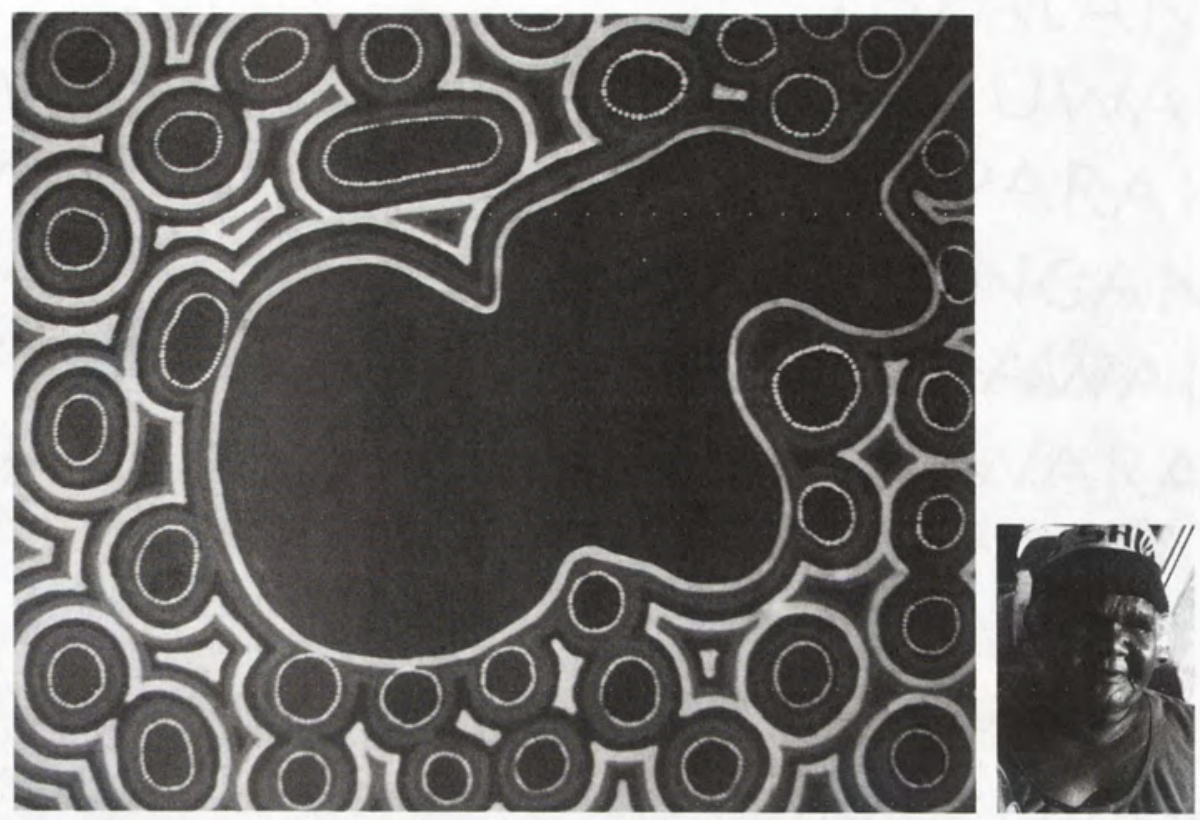

Bessie Doonday, painting of lake soakwaters in dry time
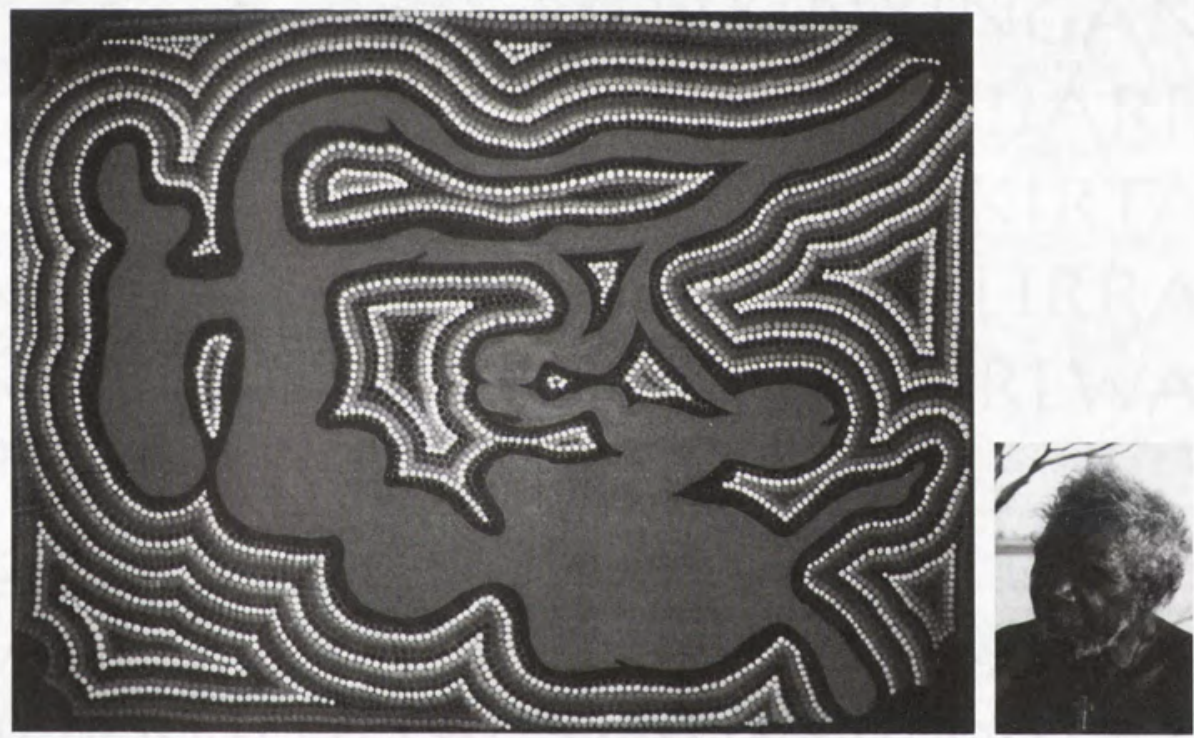

Rex Johns, painting of lake in flood time 


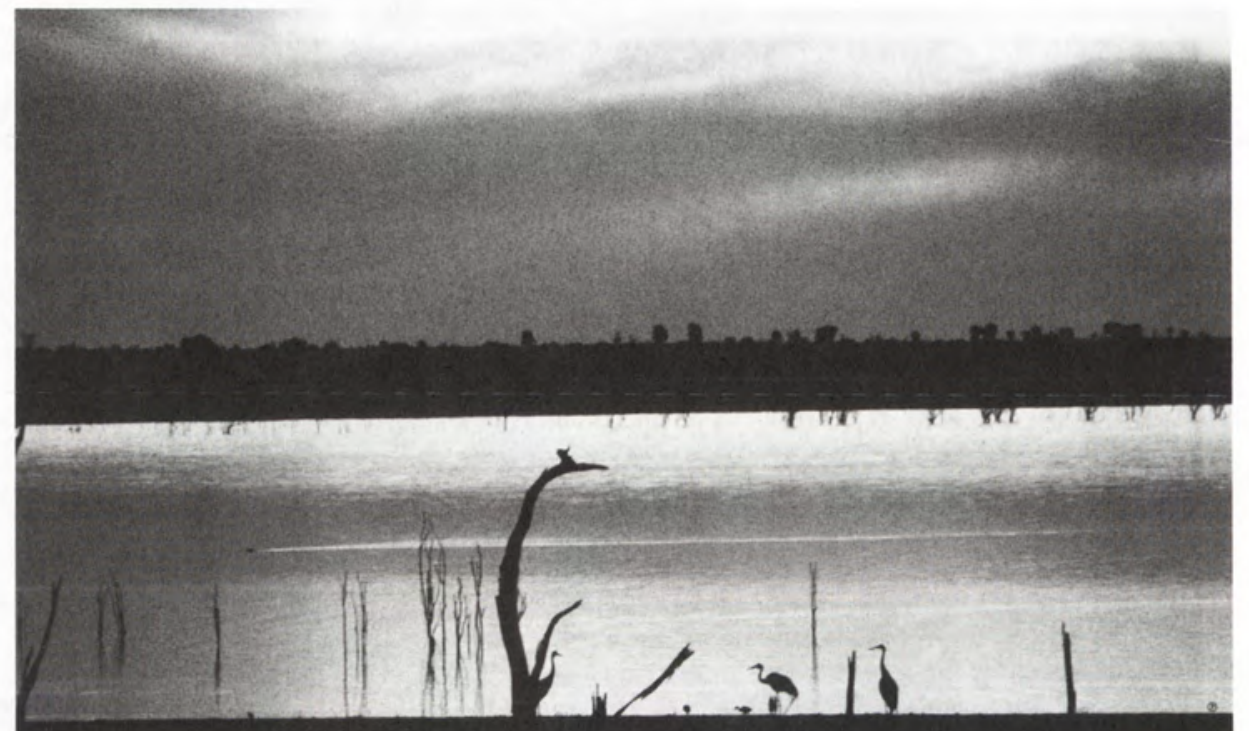

We camped at Yunpu and put the names of our ancestors on the map, in the country they came from.

We put the names of all the places where they walked, camped and went hunting.

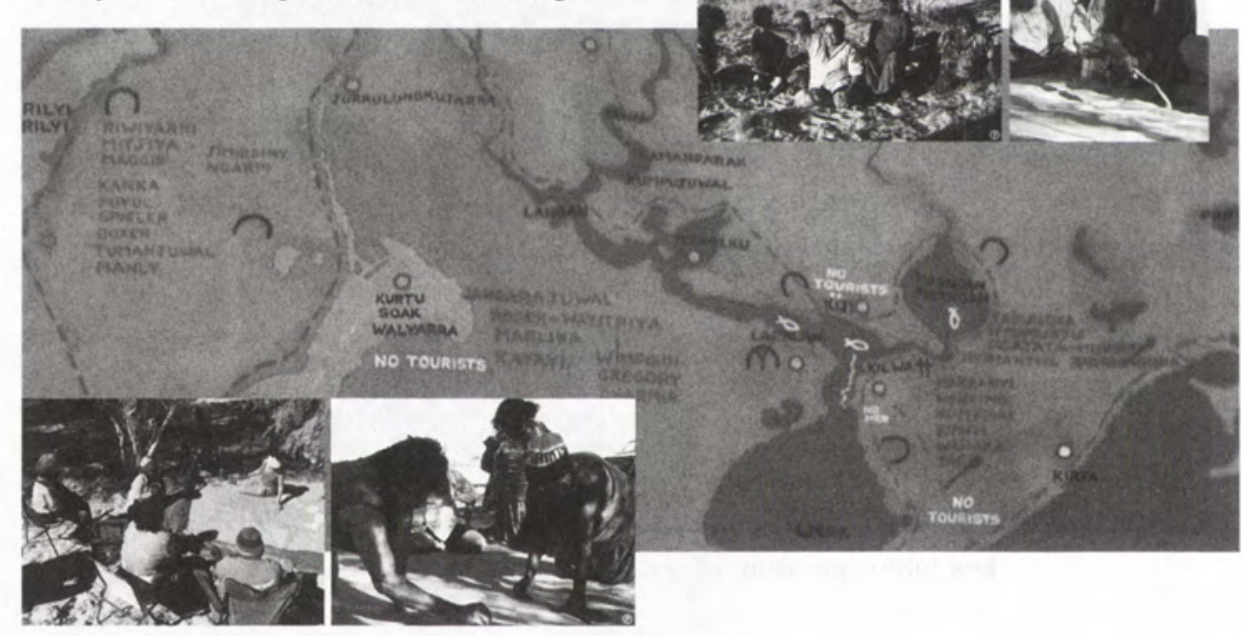




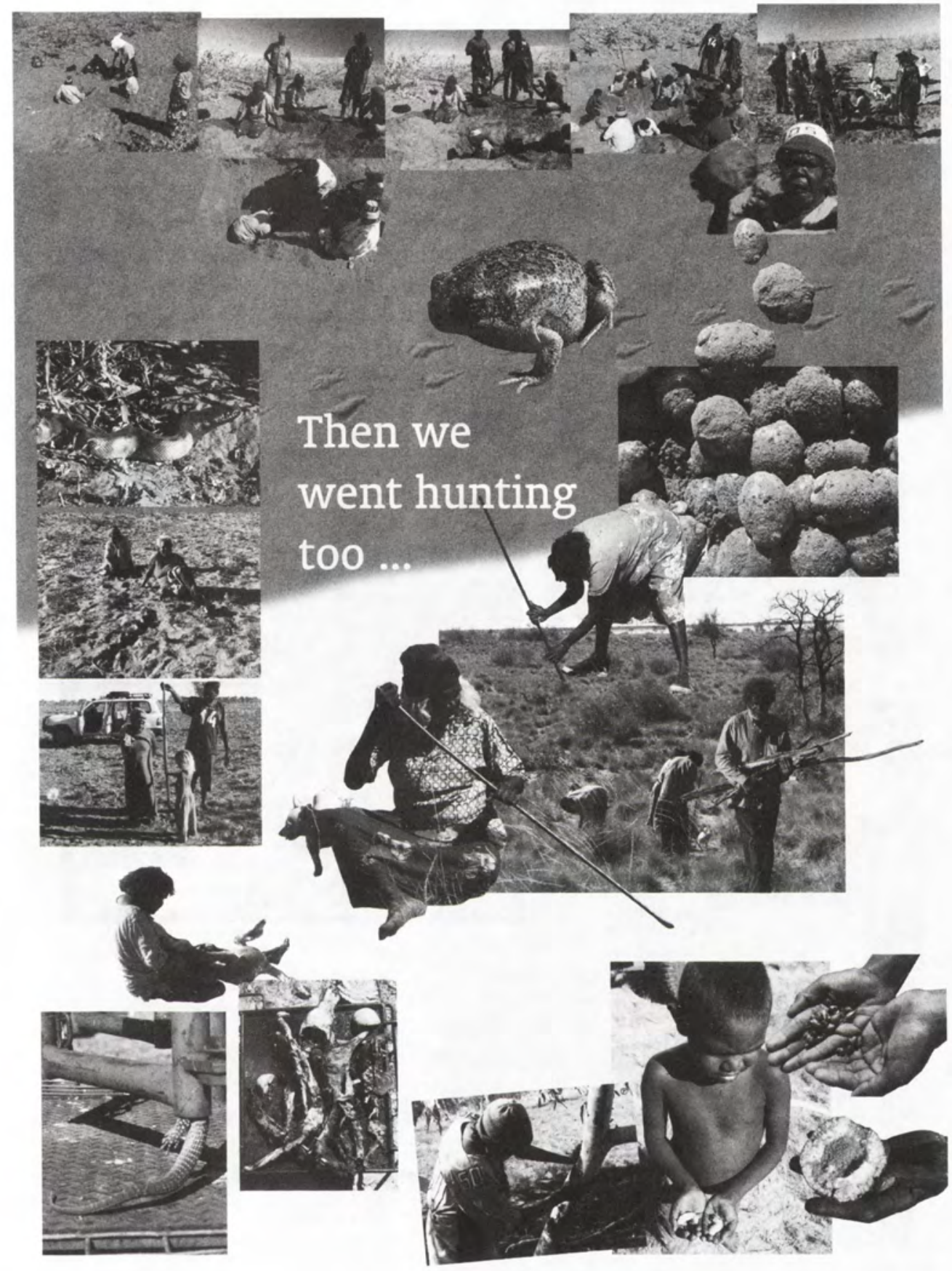




\section{Jim Bowler explained how the sand dunes around the lake were formed.}

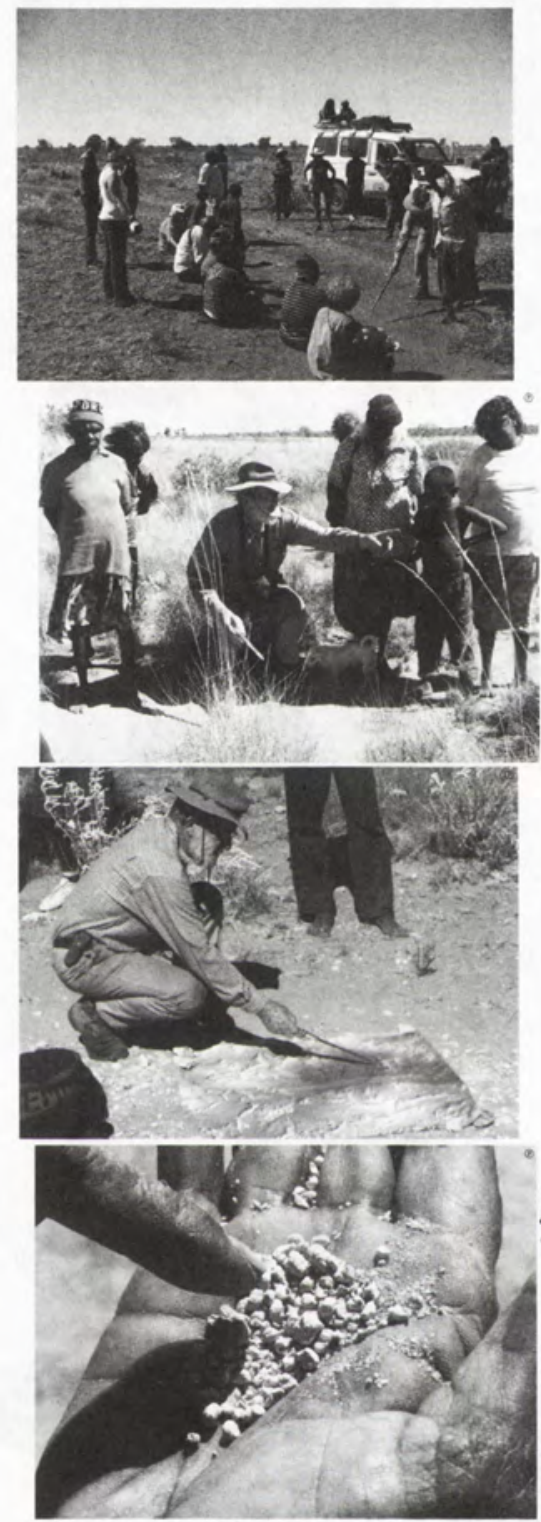

A long time ago, before people lived here, the monsoon brought much more rain to the country. 250000 years ago the lake stretched to the big sand dune east of Well 50 .

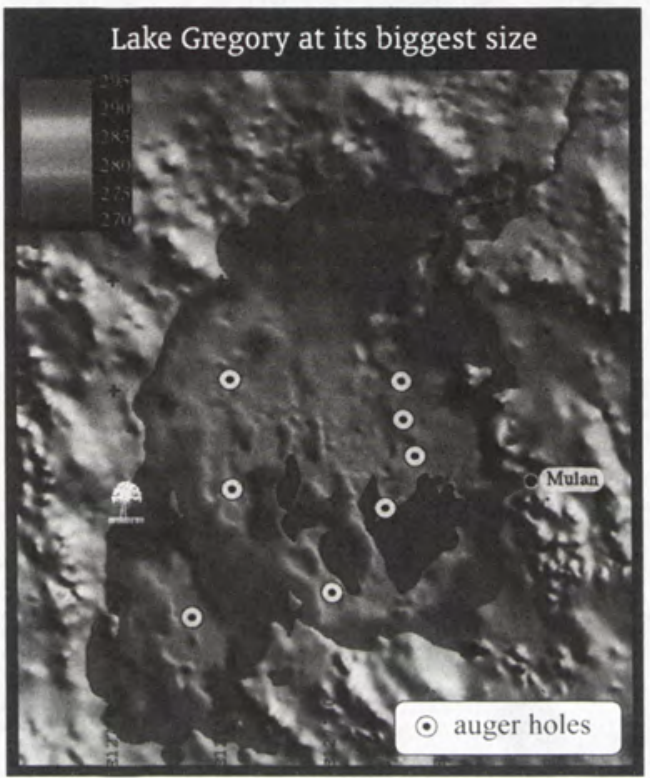

Once the lake was part of a big river that reached the sea. We have a Waljirri story that tells of how there used to be salt water fish and animals in the lake, until Jalka the great egret took them away. $\because$ 


\section{The japangarti tree stands} on the big sand dune.
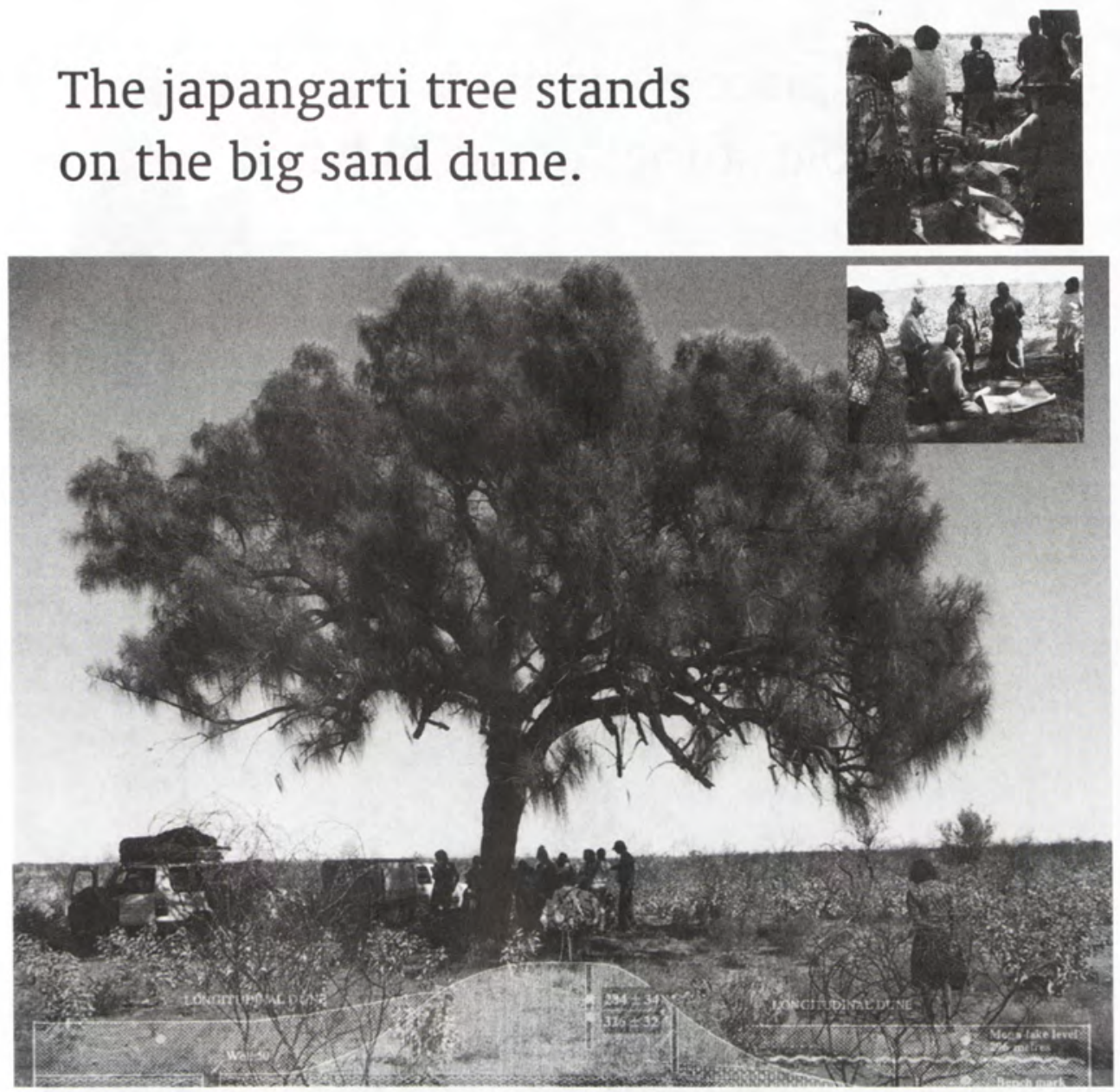

Jim Bowler drilled here and found beach sand from the old lake.
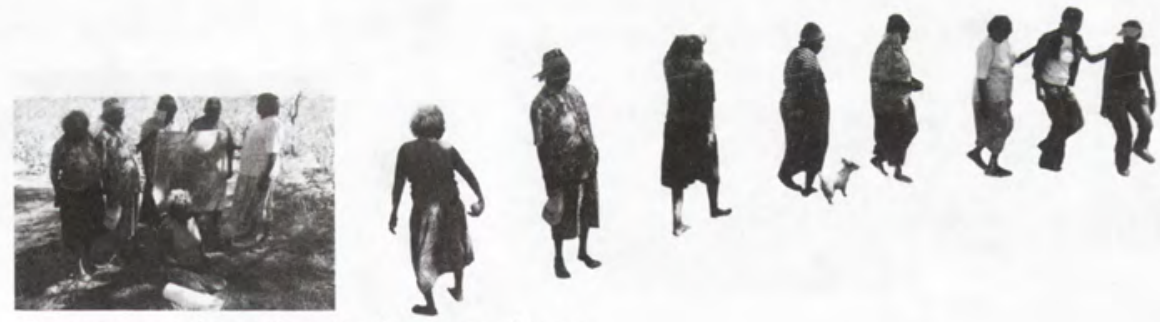

The women danced at the japangarti tree. 


\section{At every place we visited, people told stories of the old days.}

At Well 50 Evelyn Clancy told the story of how her husband walked away from the stock camp.

We recorded the stories and later wrote them down.
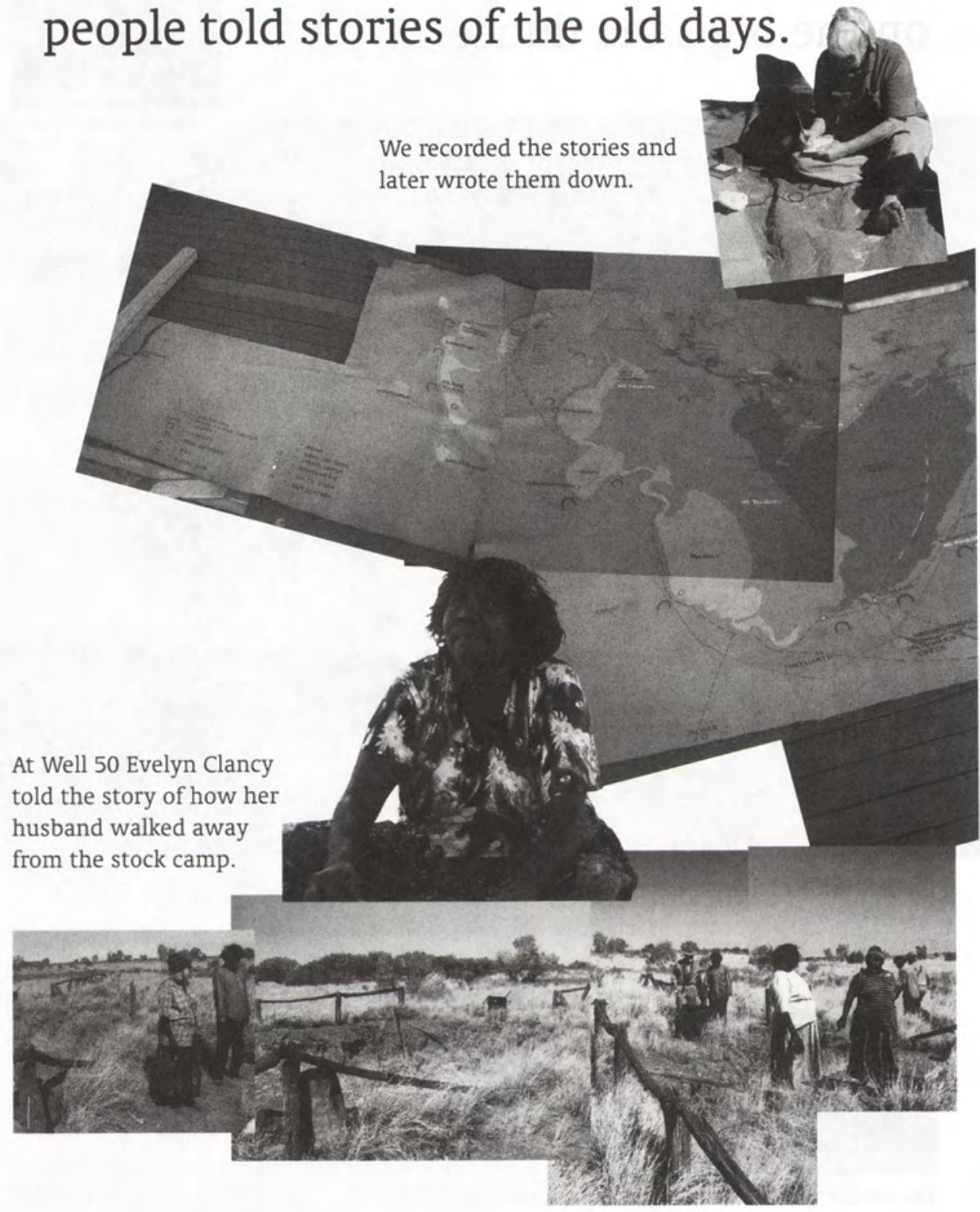


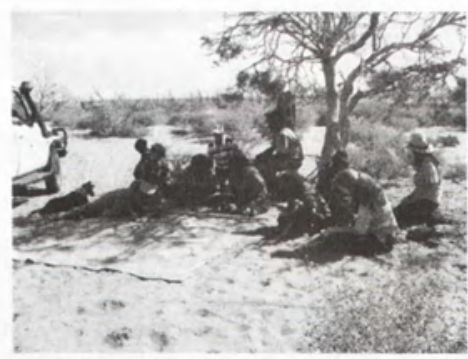

We talked about how we could look after the artefacts at the old campsites around the lake.
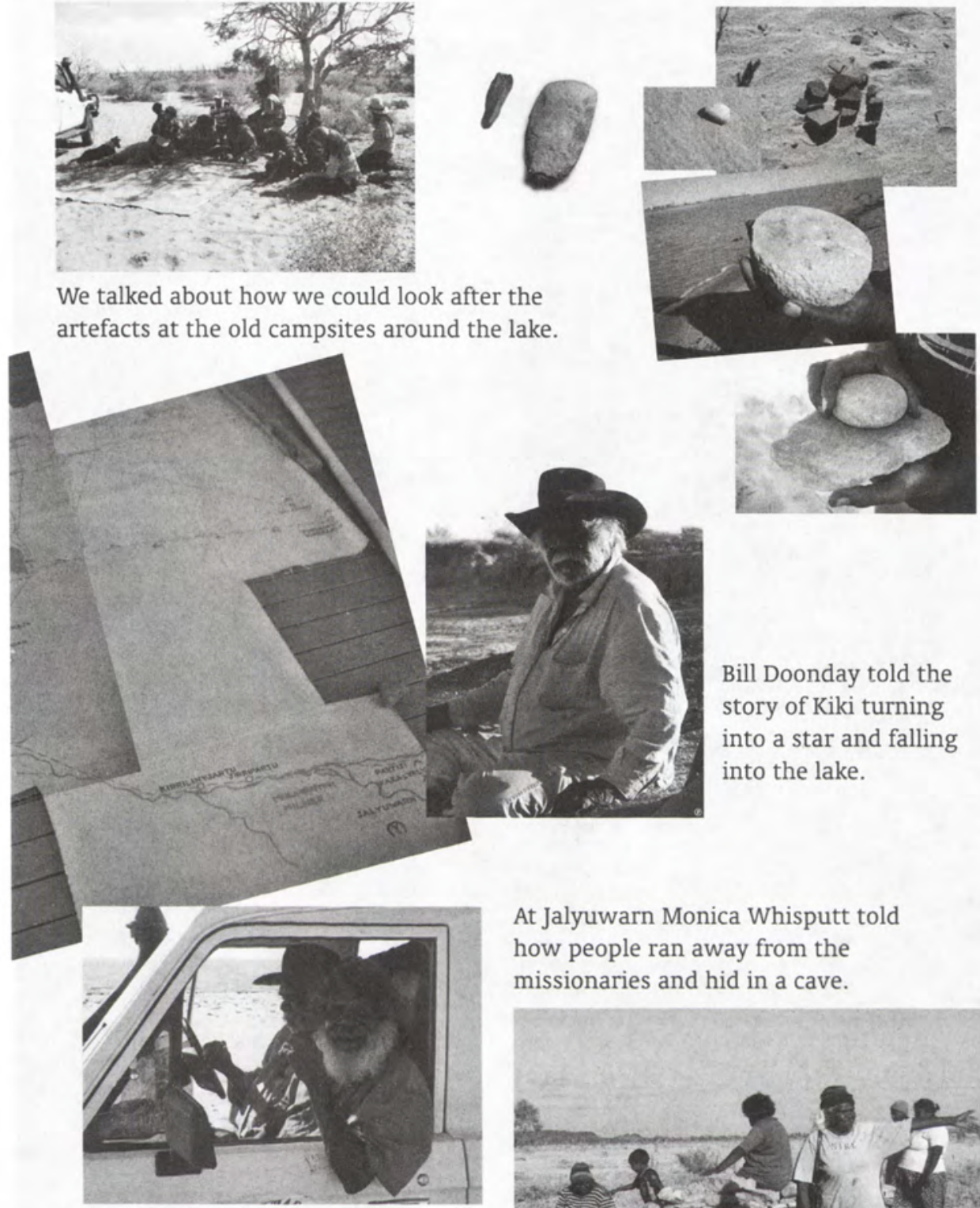

Tjilarri Matthews told his story about working as a stockman.

At Jalyuwarn Monica Whisputt told how people ran away from the missionaries and hid in a cave.

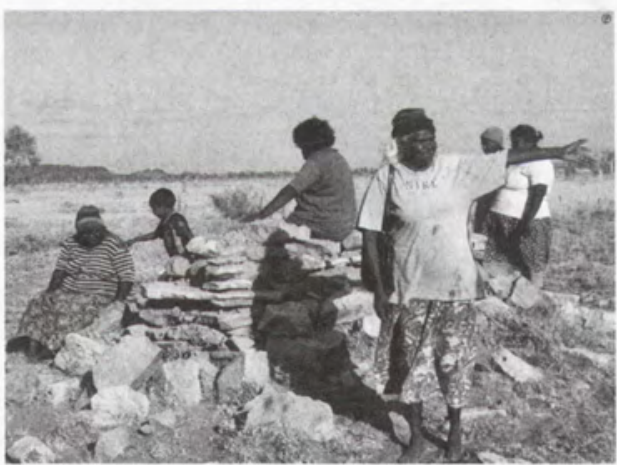




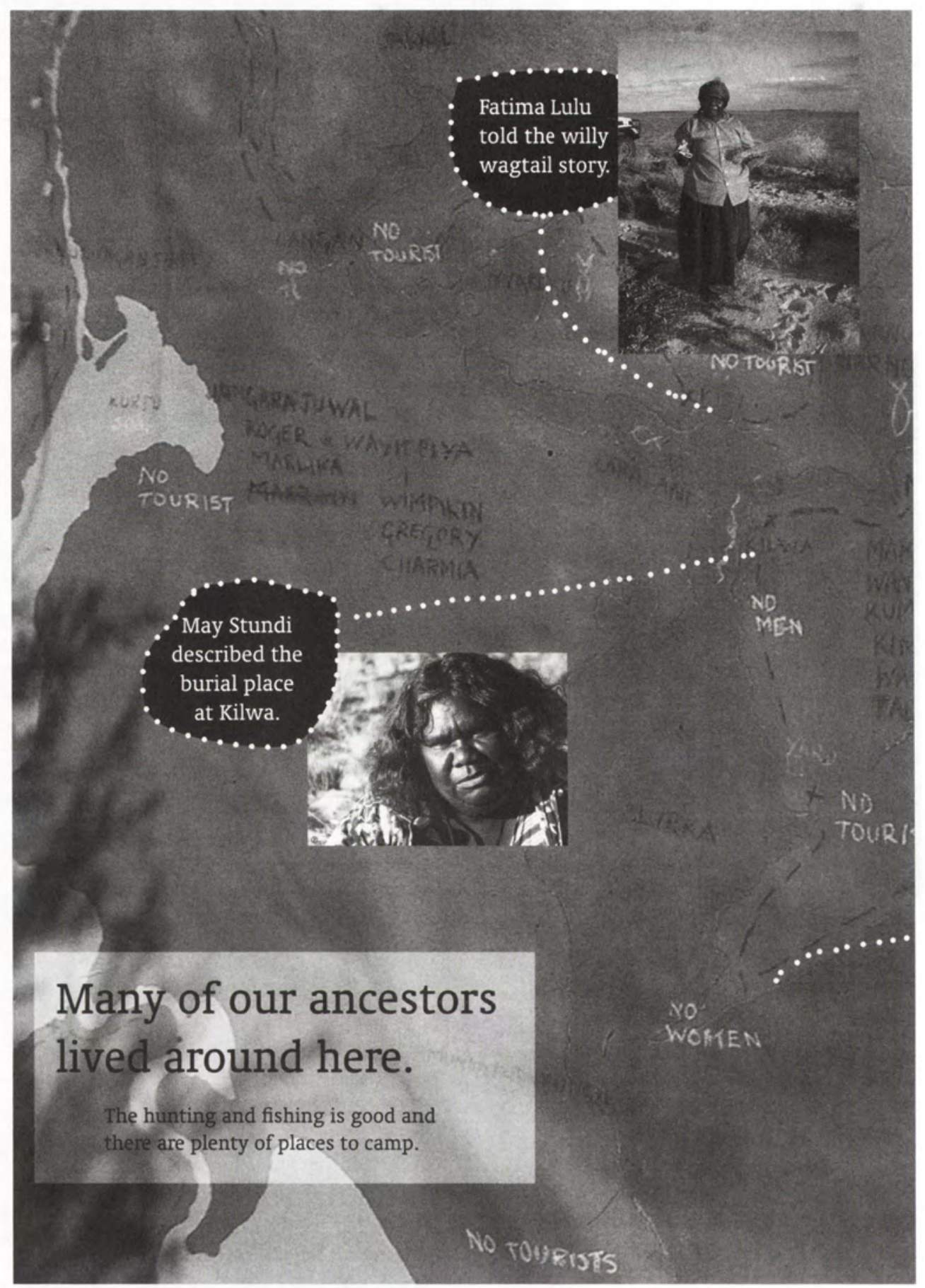




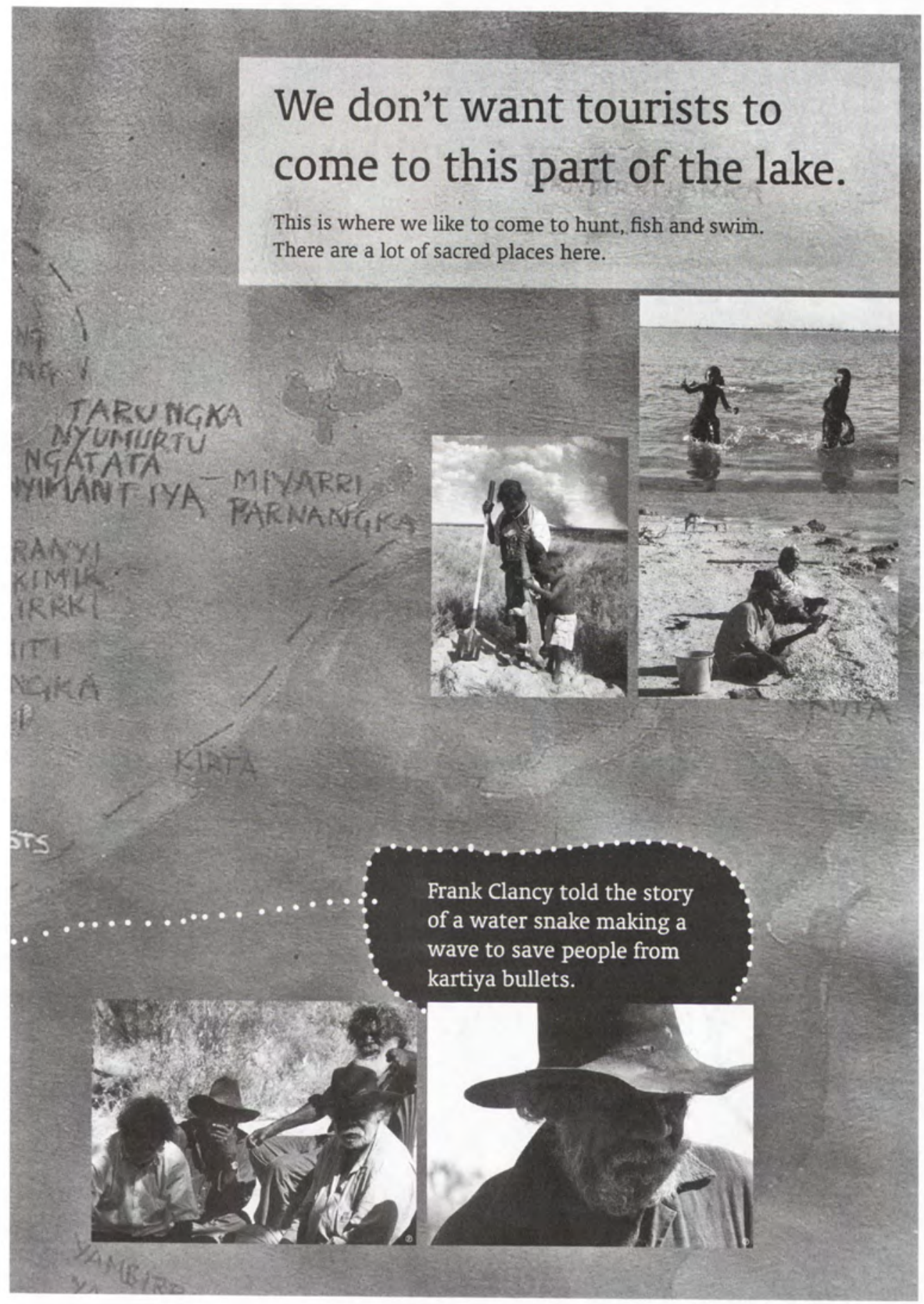




\section{The old station homestead}

\section{used to be here at Kilangkarra.}

This is where Tiger, the father of Bessie, Rex and Lulu, was blinded in an accident.
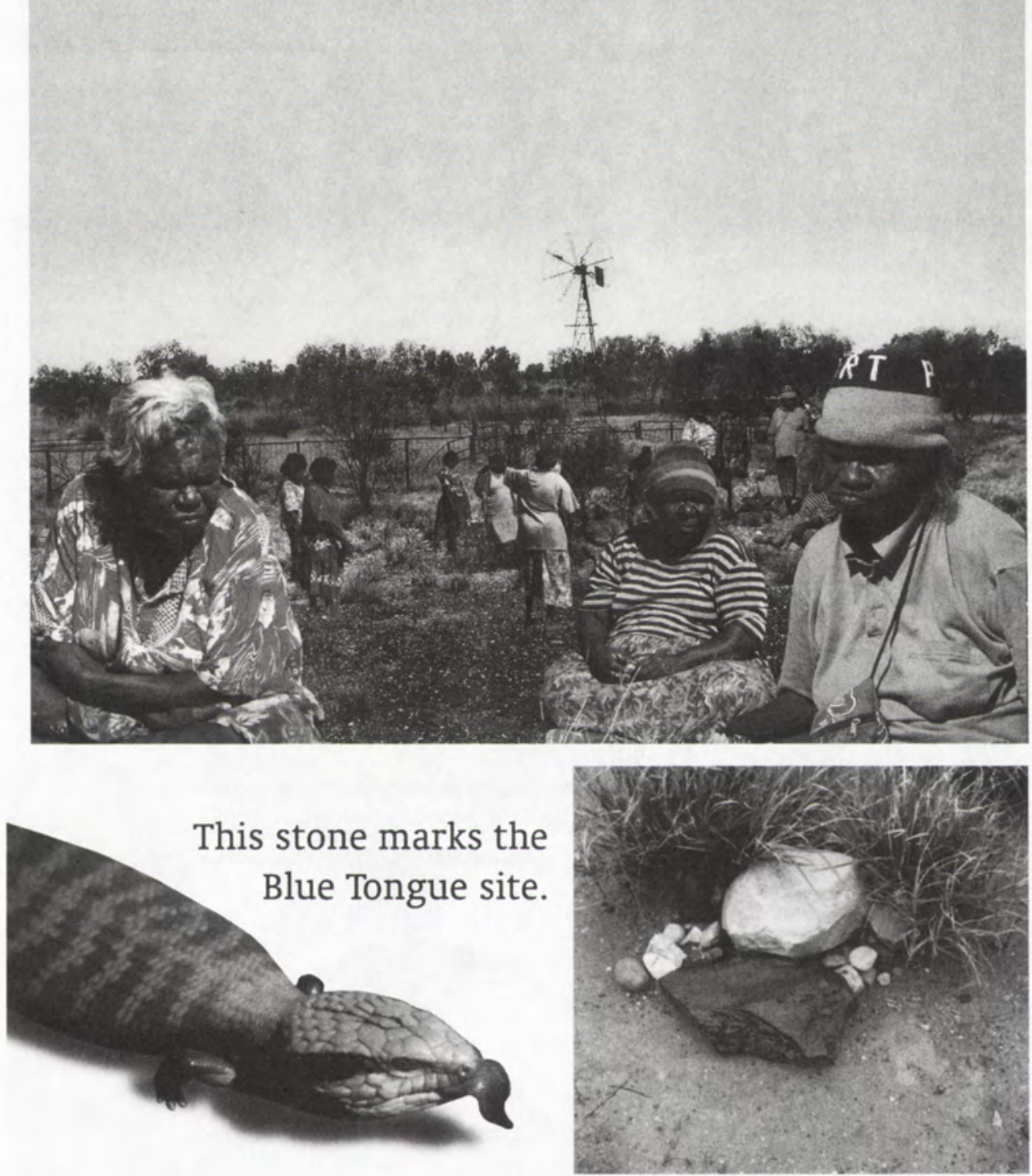

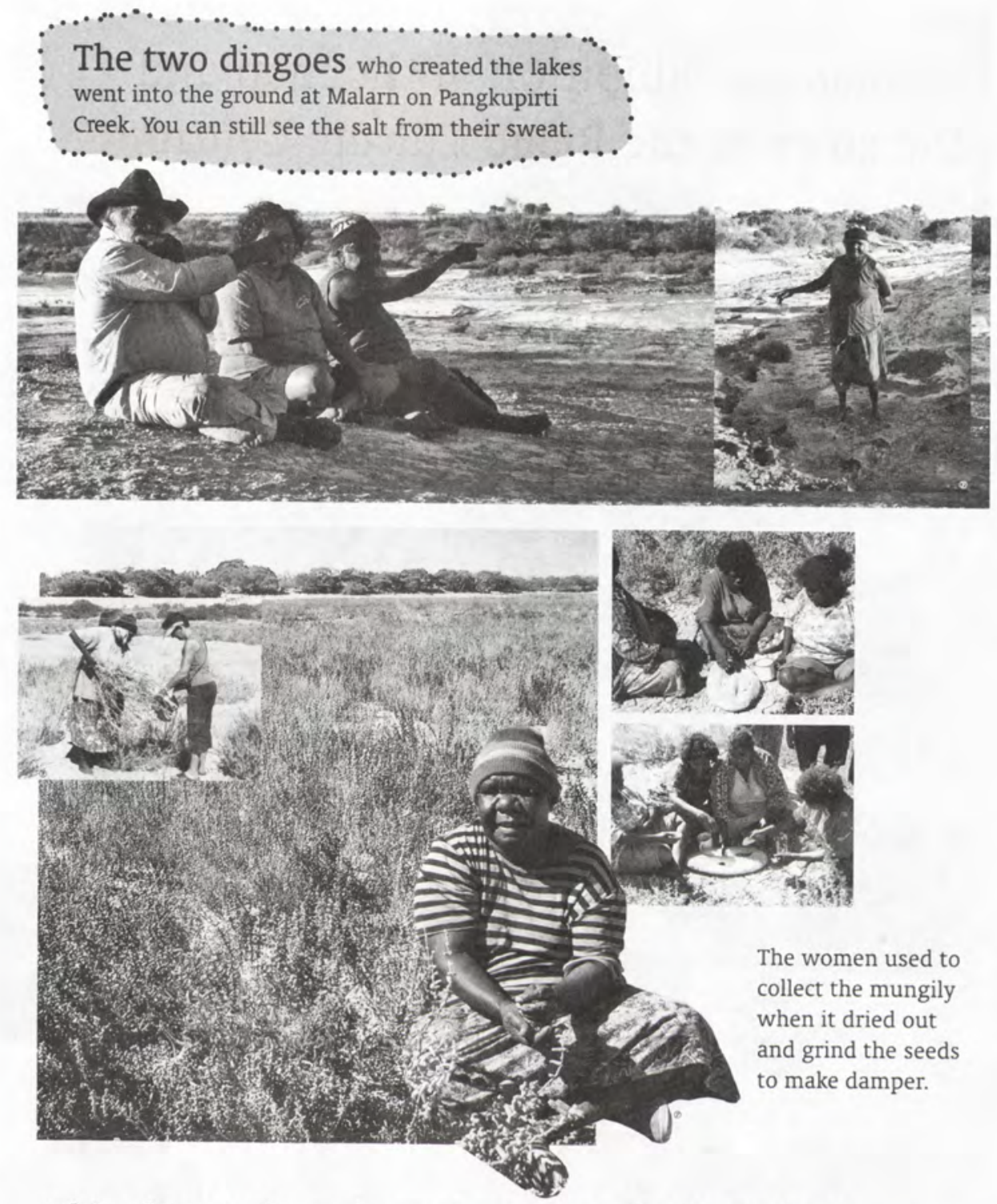

This claypan is an important place for bush food.
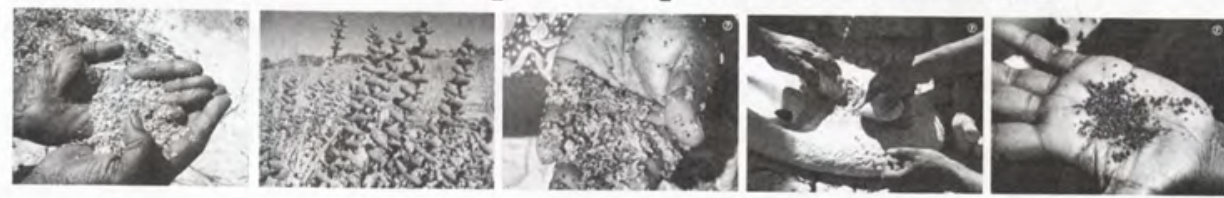
We had an exhibition of the map and the story at the Balgo Culture Centre.

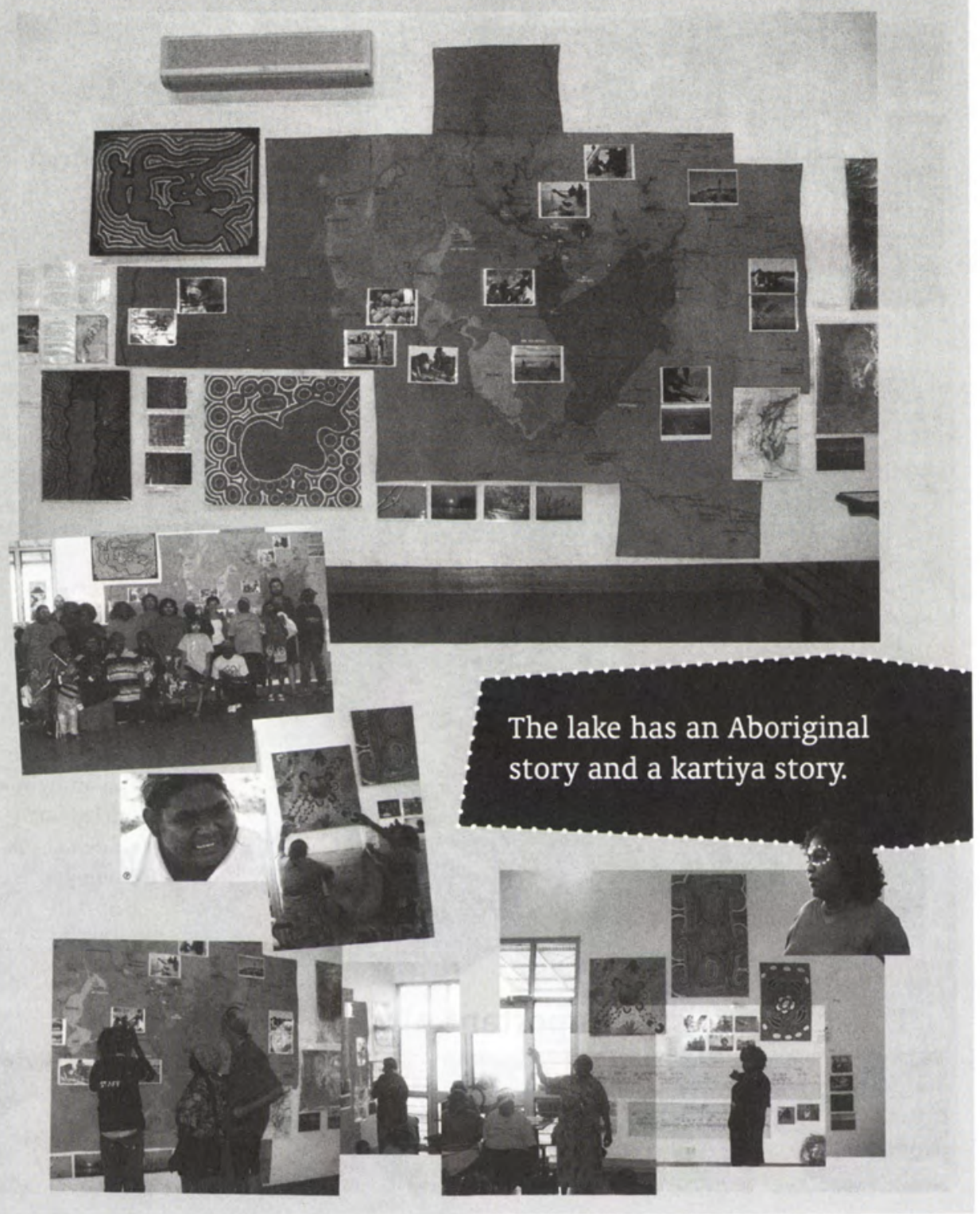




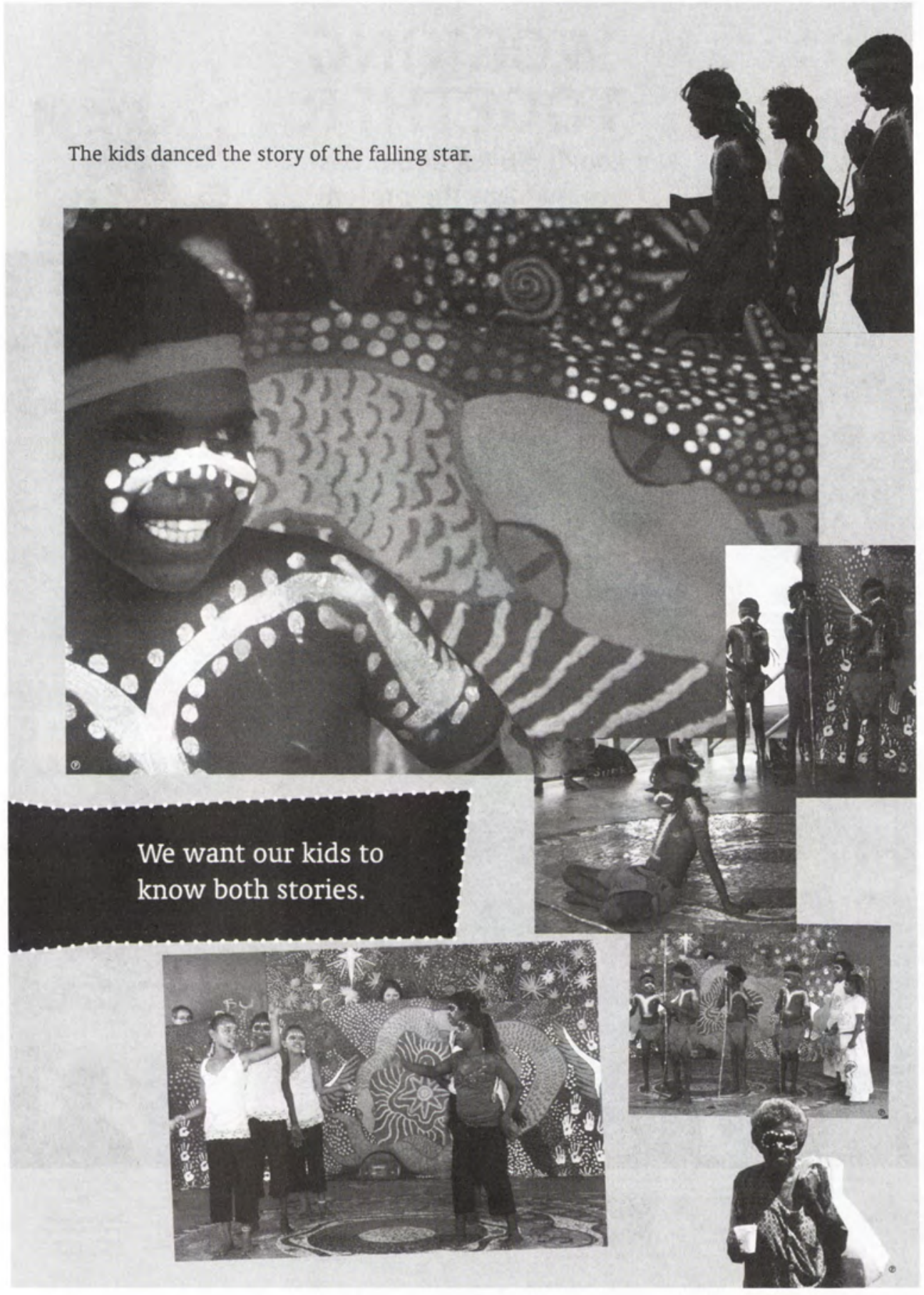




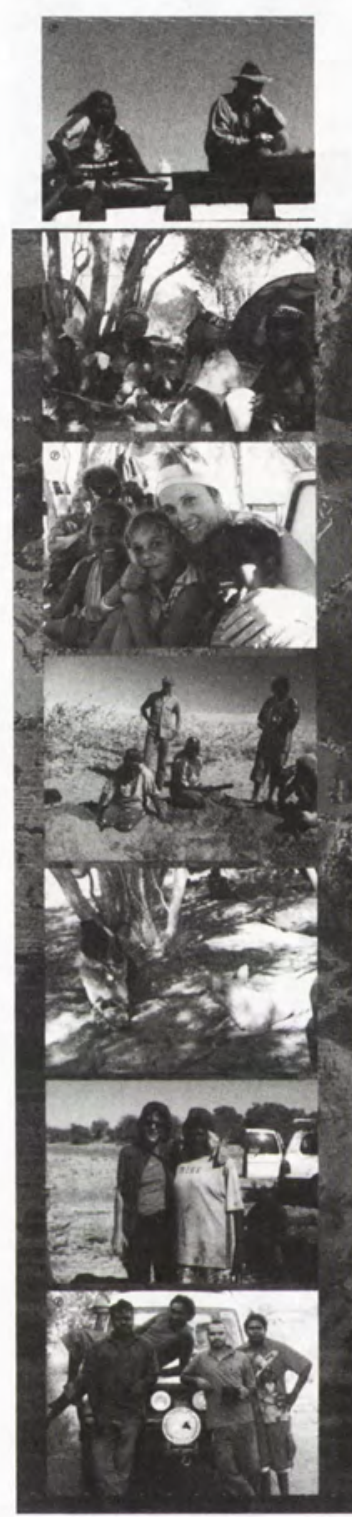

\section{WORKING TOGETHER}

Looking back at our past, to manage the present and plan for our future.
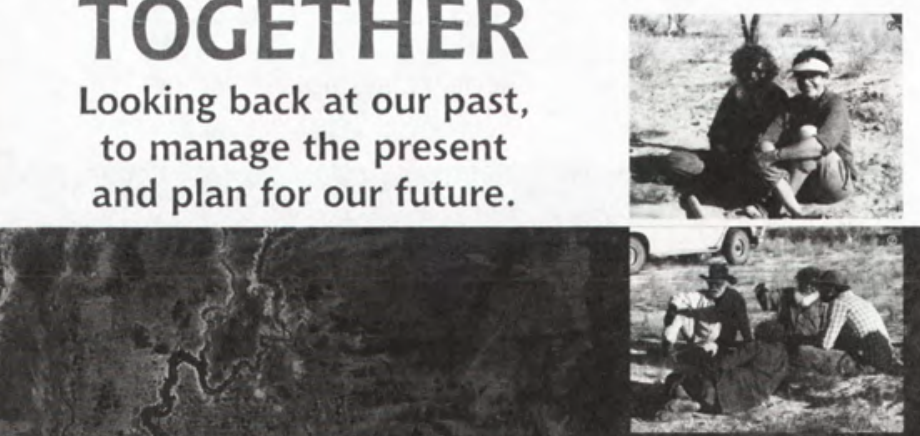

Er

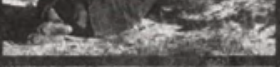

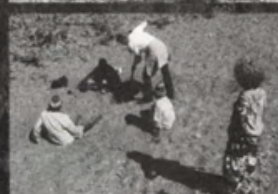

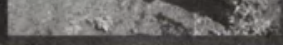
Fin
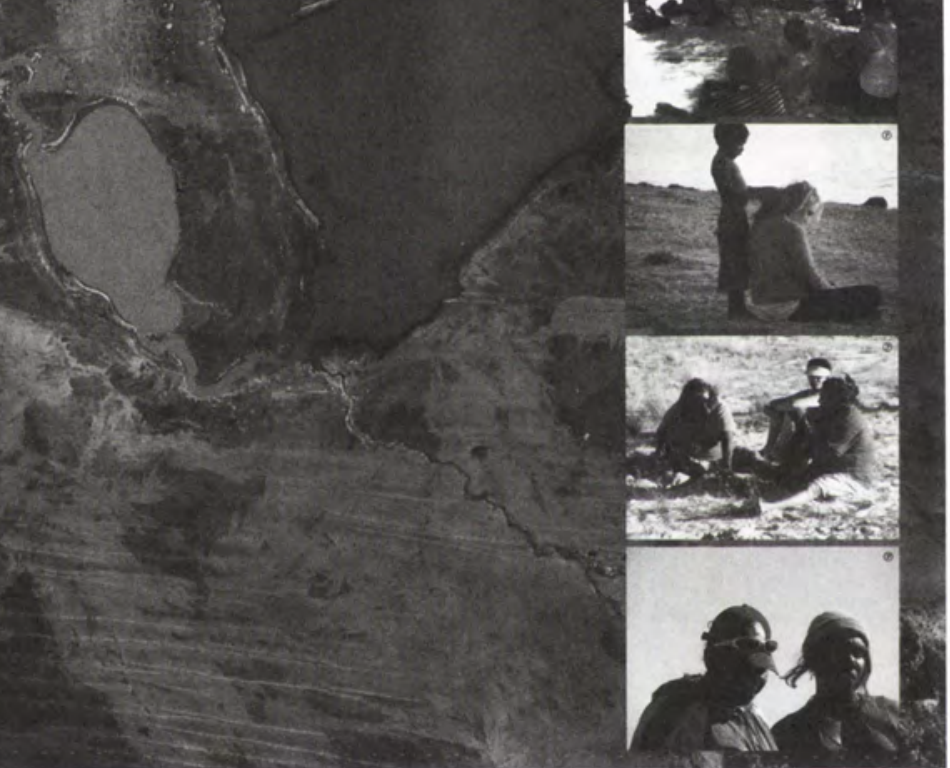

conterywest

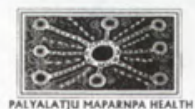

(2)

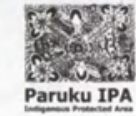

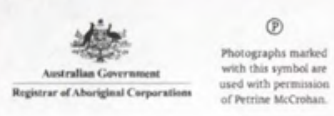

